\title{
Management of soil cover and its influence on phytosociology, physiology and fig production
}

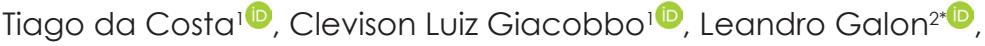 \\ César Tiago Forte ${ }^{2}{ }^{\circledR}$, Richardson Damis ${ }^{\circledR}$, Siumar Pedro Tironi ${ }^{\circledR}{ }^{\circledR}$ \\ 'Federal University of Fronteira Sul, Chapecó, Brazil \\ ${ }^{2}$ Federal University of Fronteira Sul, Erechim, Brazil \\ *Corresponding author, e-mail: leandro.galon@uffs.edu.br
}

\begin{abstract}
The fig stands out as an important source of food for the human diet, especially minerals and fibers. Weeds are a major concern in the conduct of fig orchards. Therefore, the objective of this study was to evaluate the effect of management of vegetable cover of soil (CVS) on weed phytosociology, physiological characteristics and fig production. The experimental design was a randomized complete block design with four replications. The treatments consisted of six CVS managements: cover maintenance, weeding, lodging, mowing, application of herbicides diquat and glyphosate. For the constitution of the vegetal cover a consortium of three winter forage species, vetch and black oats sowed and the ryegrass remaining in the area of previous years were used. Thus, we evaluated the phytosociology of weeds present in the area, at two different times, assigning parameters related to frequency, density and abundance, which establish the species importance value index (IVI), besides the dry mass of the aerial part of the weeds. Physiological parameters and total fruit yield were evaluated at the end of the crop cycle. The different CVS management methods influenced the weed community, mainly in the diversity, density and dry mass of the aerial part. There is no interference in the physiological variables of the fig plants and in the total production of fig fruits. We highlight the maintenance of coverage and lodging as the most promising for the management of weeds found fig orchards.
\end{abstract}

Keywords: Ficus carica, herbicide, physiological parameters

\section{Introduction}

The culture of the fig tree was one of the first fruit trees domesticated by man, especially for the excellent quality of the fruit that sparked commercial interest around the world. In Brazil around 1910, the fig cultivation started in São Paulo, later expanding to other states (Leonel, 2008). The main fig producing countries are Turkey and Egypt, Brazil stands out as the eighth largest producer, with an annual production of 25,883 tons, approximately $9,990 \mathrm{~kg} \mathrm{ha}^{-1}$ (FAO, 2019).

The fruit stands out for being a source of minerals and fiber for the human diet (Sedaghat \& Rahemi, 2018). Like all agricultural crops, fig plants can suffer from pest attack. In this scenario, the weeds showed great importance to this culture.

Weeds in addition to competing for resources such as water, light and nutrients can release allelopathic compounds (Forte et al., 2018b) and even be host pests, especially gall nematodes in the fig tree (Costa et al., 2015 ). There are several ways to control weeds in fruit growing, wherein the use of the largest possible number of methods points to a control with higher efficiency, less environmental contamination and the possibility of reducing cases of herbicide resistant species (Hanson et al., 2017; Westwood et al., 2018) or even for production focused on environmental sustainability.

Weed management is commonly employed through the use of crop control (Radicetti et al., 2013; Forte et al., 2018b; Alonso-Ayuso et al., 2018), mechanical control such as scarification (Scherner et al., 2016) and especially the chemical with the use of herbicides in different crops of agronomic interest, including fruit (Koning et al., 2019). The care that should be taken in orchards is the indiscriminate use of herbicides, which can cause drift and consequently irreversible injuries on fruit crops (Giacobbo et al., 2018).

Among the forms of weed control most commonly used in fruit growing is the use of mulch (CVS), mainly the use of green mass producing species that recycle soil nutrients. Given these factors it is possible to obtain greater productivity in the production of grains or fruits. (Wang et al., 2015; Forte et al., 2018a). To understand the 
dynamics of weed species, weeds of a particular crop, adopting different control methods has an important tool the phytosociological (Concenço et al., 2013).

The different effects of soil management systems for planting crops or even the action of herbicides on weeds can alter the botanical composition of the community (Jakelaitis et al., 2003). The floristic evolution of the community occurs according to the intensity, regularity and time of use of a given system and, depending on the intensity of these changes, may affect the management, control and competition exerted by this community with the culture (Favero et al., 2001).

The hypothesis tested in this study was that cultural managements provide lower incidence of weeds combined with a higher fruit production. The objective of the study was to evaluate the effect of soil cover management on weed phytosociology, physiological characteristics and fig production.

\section{Material and Methods}

Study site characteristics

The present work was implemented in the field in 2012 and conducted for two consecutive harvests, 2012/13 and 2013/14, in a fig orchard (Ficus carica L.), $\mathrm{cv}$. Roxo de Valinhos, municipality of São DomingosSC, latitude 26 $33^{\circ} 29$ "South, longitude 52 $31^{\circ} 54^{\prime \prime}$ West, at an altitude of $635 \mathrm{~m}$ and the soil classified as Dark Red
Latosol (EMBRAPA, 2013). The orchard was implanted on $08 / 01 / 2010$, with the open pits with a tractor-powered drill at a depth of $0.6 \mathrm{~m}, 2 \mathrm{~kg}$ of tanned cattle manure, $1.5 \mathrm{~kg}$ of poultry manure, $300 \mathrm{~g}$ dolomitic limestone and $300 \mathrm{~g} \mathrm{~N}-\mathrm{P}-\mathrm{K}$ formula 08-20-20 fertilizer were added to the pit preparation. After the orchard implantation the only form of fertilization performed was the application of 0.5 $\mathrm{kg}$ per plant, in the canopy projection, formulation 08-2020 in the middle of August of each year. The orchard has always been conducted with drastic pruning system with a limit of 22 branches.

The climate in the region corresponds to $\mathrm{Cfa}$ according to the Köppen classification. On March 29, 2014, the effect of the managements adopted on the variables related to fig plants was evaluated.

\section{Experimental design and treatments}

The experimental design was completely randomized blocks with four repetitions, six treatments, with two plants per repetition. The fig plants used were planted in $4.0 \times 3.3 \mathrm{~m}$ spacing in 2010 and conducted without irrigation, ie the test received only rainwater that happened in the region (Figure 1). The orchard is arranged in 6 lines, where the 4 central lines were used for the implementation of the experiment, leaving both ends as borders, in order to reduce possible errors related to edge effects.

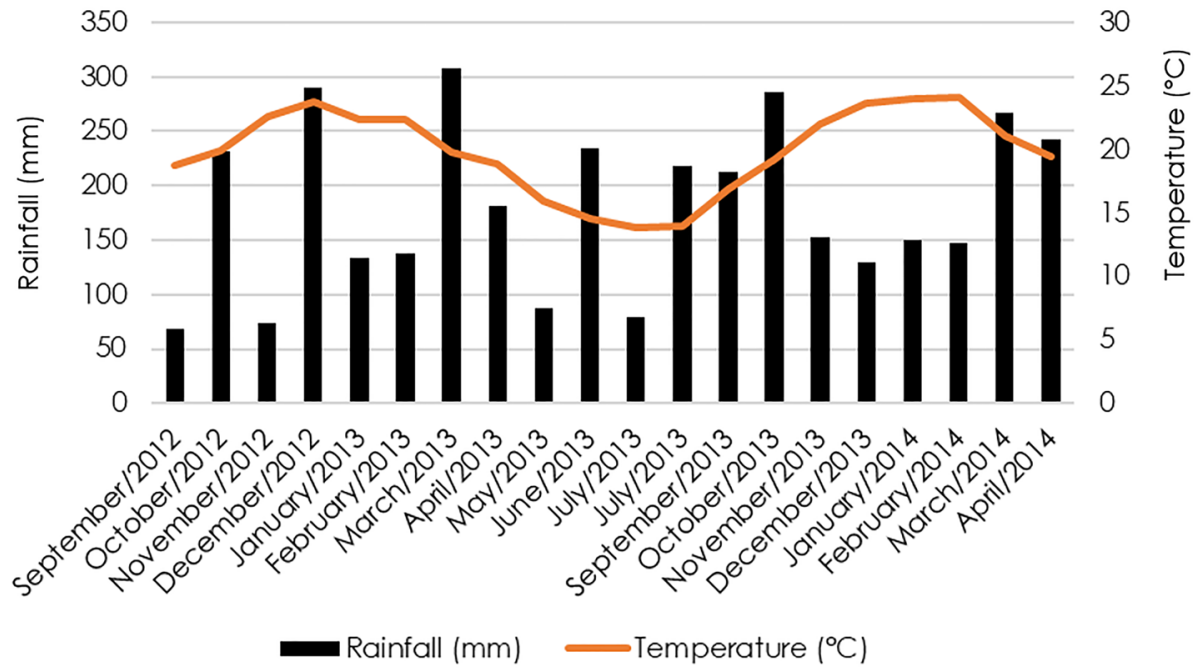

Figure 1. Climatic conditions of precipitation $(\mathrm{mm})$ and temperature $\left({ }^{\circ} \mathrm{C}\right)$ observed during the period of the experiment, from 2012 to 2014, in São Domingos, Santa Catarina, Brazil.

For the constitution of the vegetal cover a consortium of three winter forage species, vetch (Vicia sativa) and black oats (Avena strigosa) sowed and the ryegrass (Lolium multiflorum) remaining in the area of previous years were used. The black oat was implemented only in the second year in order to optimize the control of weed ryegrass. Both vetches and black oats were sown in April 2012. Before the implementation of the experiment, a chemical analysis of the soil was performed. Fertilization for the planting of fig seedlings was carried out according to soil analysis and following the technical recommendations for fig tree cultivation 
(ROLAS, 2004). The chemical and physical characteristics of the soil were: $\mathrm{pH}$ in water of $6.3 ; \mathrm{MO}=4.2 \% ; \mathrm{P}=3.4 \mathrm{mg}$ $\mathrm{dm}^{-3} ; \mathrm{K}=188.0 \mathrm{mg} \mathrm{dm}^{-3} ; \mathrm{Al}^{3+}=0.0 \mathrm{cmolc} \mathrm{dm}^{-3} ; \mathrm{Ca}^{2+}=6.9$ cmolc dm ${ }^{-3} ; \mathrm{Mg}^{2+}=4.2 \mathrm{cmolc} \mathrm{dm}^{-3} ; \mathrm{CTC}(\mathrm{t})=11.58 \mathrm{cmolc}$

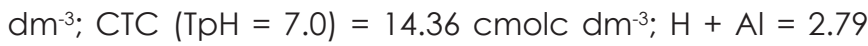

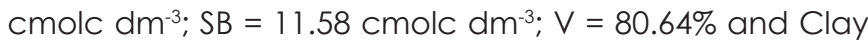
$=43 \%$.

The treatments tested for the management of vegetation cover were: cover maintenance, weeding, lodging, mowing, application of the herbicides of diquat

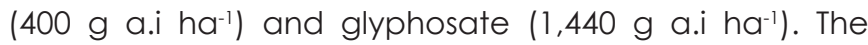
weeding was carried out normally, with the help of manual hoe. The herbicides were applied by spraying pressurized $\mathrm{CO}_{2}$ precision, equipped with a series of spraying $\mathrm{XR}$ 1 10.02, spraying one spray volume of $150 \mathrm{~L} \mathrm{ha}^{-1}$. For lodging treatment, the action of the knife roll was simulated, with the kneading of the vegetable material and cutting with cutting material. For the mowing treatment, the plants were cut with the aid of costal mower on average $5 \mathrm{~cm}$. The treatments were applied when the oat plants were in the milky grain phase. Two fig plants comprised each experimental unit, and the treatments were applied in an area of $4 \mathrm{~m}^{2}$ around each plant.

\section{Evaluated variables}

The variables evaluated were the incidence of weeds (dry matter of the aerial part of the species), physiological parameters of fig plants, mature fruit productivity fig (for in natura consumption), green fruit productivity (for storage) and cumulative productivity.

The incidence of weeds was determined with the aid of a hollow square with a known area $\left(0.25 \mathrm{~m}^{2}\right)$, randomly casting it in two of the quadrants of one of the plants of each experimental unit (Concenço et al., 2013). Plants contained within the perimeter of the square were quantified, identified and subsequently dried in a forced air circulation oven at $60 \pm 5^{\circ} \mathrm{C}$ to constant dry mass (DM).

The variables related to the physiology of fig plants were evaluated on 28, 29,30 and 31 March 2014, as follows: internal $\mathrm{CO}_{2}$ concentration $\left(\mathrm{Ci}-\mu \mathrm{mol} \mathrm{mol}^{-1}\right.$ ), transpiration rate $\left(\mathrm{E}-\mathrm{mol} \mathrm{H} \mathrm{O} \mathrm{m}^{-2} \mathrm{~s}^{-1}\right.$ ), stomatal conductance of water vapors ( $\mathrm{Gs}-\mathrm{mol} \mathrm{m}^{-1} \mathrm{~s}^{-1}$ ), and photosynthetic efficiency (A - $\mu \mathrm{mol} \mathrm{m}^{-2} \mathrm{~s}^{-1}$ ), water-use-efficiency (WUE - mol $\mathrm{CO}_{2}$ mol $\mathrm{H}_{2} \mathrm{O}^{-1}$ ) carboxylation efficiency (CE- mol $\mathrm{CO}_{2} \mathrm{~m}^{-2} \mathrm{~s}^{-1}$ ) measured in the middle third of the first fully expanded leaf of the plants. Carboxylation efficiency (CE - $\mathrm{mol} \mathrm{CO}_{2}$ $\mathrm{m}^{-2} \mathrm{~s}^{-1}$ ) and water-use-efficiency (WUE - mol $\mathrm{CO}_{2} \mathrm{~mol}_{2} \mathrm{O}$ 1) were calculated from the ratio of variables $\mathrm{A} / \mathrm{Ci}$ and A / E, respectively. For this purpose, an ADC-branded infrared gas analyzer (IRGA), model LCA PRO (Analytical
Development Co. Ltd, Hoddesdon, UK) was used; Each block was evaluated under natural light on one day, between 8:00 AM and 10:00 AM, under clear skies, so as to maintain homogeneous environmental conditions during the analyzes.

The productivity variable was determined by counting and weighing the fruits on a precision scale. Once reaching physiological maturity, the fruits were collected separately from two randomly selected branches in one of the plants of each experimental unit at the beginning of fruiting (Giacobbo et al., 2007). Fruits that did not reach physiological maturity due to climate changes at the end of the cycle were also counted and weighed in a single day, measuring the total length of the selected branch in order to obtain the number of fruits per meter of branch.

\section{Competitive indices and statistical analysis}

With the data obtained, the phytosociological indices were calculated: relative density (RDe), relative frequency (Rf) and relative abundance (Rab), which are used to calculate the Importance Value Index (IVI), according to the methodology proposed by MüellerDombois \& Ellemberg (1974), in which:

- Frequency $=$ Number of squares in which the species was found / total number of square

- Density = Total number of individuals of the species / total number of squares

- Abundance $=$ Total number of individuals of the species / Total number of squares where the species was found

- Relative density (RDe) = (species density / total species density) x 100

- Relative frequency $(\mathrm{Rf})=$ (species frequency $/$ total species frequency) $\times 100$

- Relative abundance (Rab) = (species abundance / total species abundance) $\times 100$

$-\mathrm{IVI}=\mathrm{RDe}+\mathrm{Rf}+\mathrm{Rab}$

For physiological characteristics and the final fruit production, all data were evaluated for normal distribution and homoscedasticity were later submitted to analysis of variance, with the same significance were compared by Tukey test at $\mathrm{p} \leq 0.05$.

\section{Results and Discussion}

Phytosociological parameters

During the evaluation period of the experiment, it was possible to observe the presence of 14 families and 23 species of weeds (Table 1). The families with the highest number of species present in the area were Asteraceae 
and Poaceae, both represented by four species.

The predominance of these families in the conducting region of the study is common. In works realized by the author Santi et al. (2014) in soybean crop and Forte et al. (2018b) in annual crops in southern Brazil, report the predominance of these weed families in their phytosociological studies.

Table 1. Distribution of weeds by family, species and popular name collected in fig orchard under different management methods. São Domingos, Santa Catarina, Brazil.

\begin{tabular}{|c|c|c|}
\hline Family & Scientific name of species & Popular species name \\
\hline \multirow{2}{*}{ Amaranthaceae } & Amaranthus hibridus & Caruru \\
\hline & Dysphania ambrosioides & Erva-de-santa-maria \\
\hline \multirow{4}{*}{ Asteraceae } & Bidens pilosa & Picão-preto \\
\hline & Conyza bonariensis. & Buva \\
\hline & Sonchus oleraceus & Serralha \\
\hline & Taraxacum officinalis & Dente-de-leão \\
\hline Brassicaceae & Raphanus sativus. & Nabo \\
\hline Convolvulaceae & Ipomoea purpurea & Corda-de-viola \\
\hline \multirow{2}{*}{ Euphorbiaceae } & Chamaesyce hirta & Erva-de-santa-luzia \\
\hline & Euphorbia heterophylla & Leiteiro \\
\hline Fabaceae & Trifolium repens. & Trevo-branco \\
\hline \multirow{2}{*}{ Lamiaceae } & Leonurus japonicas & Rubim \\
\hline & Stachys arvensis & Rabo-de-raposa \\
\hline Malvaceae & Sida rhombifolia & Guanxuma \\
\hline Plantaginaceae & Plantago lanceolata. & Tansagem \\
\hline \multirow{4}{*}{ Poaceae } & Eleusine indica & Capim-pé-de-galinha \\
\hline & Digitaria horizontalis & Milhã/capim-colchão \\
\hline & Panicun maximum & Capim-colonião \\
\hline & Urochloa plantaginea & Papuã/capim-marmelada \\
\hline Polygonaceae & Rumex obtusifolius & Lingua-de-vaca \\
\hline Portulacaceae & Portulaca oleracea & Beldroega \\
\hline Rubiaceae & Richardia brasiliensis & Poaia-branca \\
\hline Solanaceae & Solanum americanum & Maria-pretinha \\
\hline
\end{tabular}

First evaluation

According to the results found for the phytosociological parameters it is possible to verify, in the first evaluation, that the species Euphorbia heterophylla presented the highest importance value index (IVI) and the largest number of plants $\mathrm{m}^{-2}$, except for the weed management (Figure 2 and Table 1). Possibly, the higher seed covering with soil in weeding management may have provided the largest germination, since the highest IVI was found for Euphorbia heterophylla. Smith et al. (1992) observed the occurrence of emergency Sida rhombifolia maximum when the depth was from 0.5 to $2 \mathrm{~cm}$, which corroborates in part with the present study. Relative density was the parameter that most contributed to increase IVI, regardless of the cover management method adopted (Figure 2).

Euphorbia heterophylla presented higher frequency and relative abundance in the treatments where the cover management methods used were: chemist with the application of Diquat herbicide and glyphosate and scuffed, highlighting how these methods may contribute significantly to the appearance of the species, both due to their low efficiency, due to their stage of development and resistance to herbicides, growing continuously.

Among the methods of soil cover management, mowing showed the highest density and dry mass of weeds, the increase was 207, 116, 199, 144 and 121 plants $\mathrm{m}^{-2}$ and $15,131,92,127$ and $136 \mathrm{~g} \mathrm{~m}^{-2}$ compared to the maintenance of mowing, lodging, diquat and glyphosate coverings, respectively (Table 2). The mowing of Avena strigosa of vegetation provides changes in soil temperature, light input and consequently decreased microbial activity (Zibilske \& Makus, 2009), these results can contribute to the emergence of species of positive photoblastic weeds or in need of temperature alternation.

The glyphosate herbicide provided the lowest species diversity (Figure 2) and the lowest dry mass of weeds (Table 2). The smallest number of plants has already been observed in the maintenance of soil cover, with $26 \mathrm{~m}^{-2}$ of plants. Koning et al. (2019) show the favoring of some species over others due to the weed management method, root and rhizome propagation species and weeds without seasonality were favored by glyphosate application. 

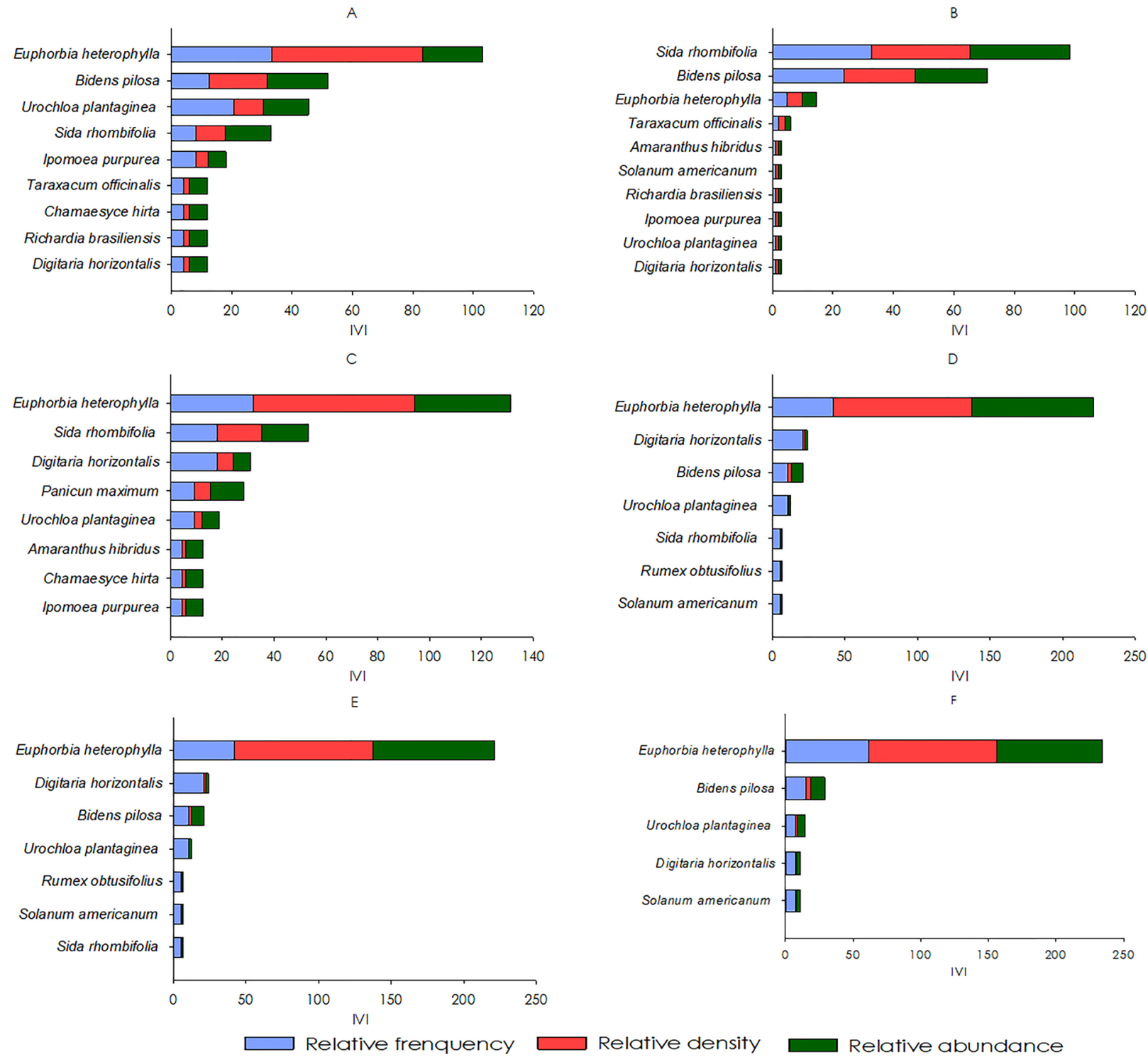

Figure 2. Importance value index (IVI) of weeds in fig under the influence of different managements (A) cover maintenance, (B) weeding, (C) lodging, (D) mowing, (E) herbicide diquat and (F) glyphosate herbicide in weed control. São Domingos, Santa Catarina, Brazil.

Table 2. Number of plants (NP) by species $\left(\mathrm{m}^{-2}\right)$ and shoot dry mass (DM) $\left(\mathrm{g} \mathrm{m}^{-2}\right)$ in the different weed control methods in fig. São Domingos, Santa Catarina, Brazil.

\begin{tabular}{|c|c|c|c|c|c|c|c|c|c|c|c|c|}
\hline \multirow[t]{2}{*}{ Species } & \multicolumn{2}{|c|}{$\begin{array}{c}\text { Cover } \\
\text { maintenance }\end{array}$} & \multicolumn{2}{|c|}{ Weeding } & \multicolumn{2}{|c|}{ Lodging } & \multicolumn{2}{|c|}{ Mowing } & \multicolumn{2}{|c|}{ Diquat } & \multicolumn{2}{|c|}{ Glyphosate } \\
\hline & NP & DM & NP & $\mathrm{DM}$ & NP & DM & NP & $\mathrm{DM}$ & NP & DM & NP & DM \\
\hline Sida rhombifolia & 3 & 22 & 66 & 6 & 6 & 3 & 1 & 1 & 1 & 0 & 0 & 0 \\
\hline Digitaria horizontalis & 1 & 58 & 1 & 0 & 2 & 34 & 3 & 53 & 2 & 9 & 1 & 2 \\
\hline Urochloa plantaginea & 3 & 51 & 1 & 11 & 1 & 9 & 1 & 109 & 4 & 1 & 1 & 2 \\
\hline Euphorbia heterophylla & 13 & 7 & 7 & 3 & 20 & 15 & 220 & 13 & 79 & 39 & 105 & 36 \\
\hline Ipomoea purpurea & 1 & 1 & 1 & 1 & 1 & $0^{*}$ & 0 & 0 & 0 & 0 & 0 & 0 \\
\hline Bidens pilosa & 5 & 19 & 36 & 28 & 0 & 0 & 6 & 10 & 3 & 9 & 4 & 7 \\
\hline Richardia brasiliensis & 1 & 10 & 1 & 3 & 0 & 0 & 0 & 0 & 0 & 0 & 0 & 0 \\
\hline Chamaesyce hirta & 1 & 1 & 0 & 0 & 1 & $0^{*}$ & 0 & 0 & 0 & 0 & 0 & 0 \\
\hline Taraxacum officinalis & 1 & 1 & 2 & 2 & 0 & 0 & 0 & 0 & 0 & 0 & 0 & 0 \\
\hline Amaranthus hibridus & 0 & 0 & 1 & $0^{*}$ & 1 & 4 & 0 & 0 & 0 & 0 & 0 & 0 \\
\hline Panicun maximum & 0 & 0 & 0 & 0 & 2 & 28 & 0 & 0 & 0 & 0 & 0 & 0 \\
\hline Solanum americanum & 0 & 0 & 1 & $0^{*}$ & 0 & 0 & 1 & $0^{*}$ & 0 & 0 & 1 & 0* \\
\hline Rumex obtusifolius & 0 & 0 & 0 & 0 & 0 & 0 & 1 & $0^{*}$ & 0 & 0 & 0 & 0 \\
\hline Total & 26 & 170 & 117 & 54 & 34 & 93 & 233 & 185 & 89 & 58 & 112 & 49 \\
\hline
\end{tabular}




\section{Second evaluation}

In the second phytosociological survey, carried out in December (20 months after the application of the treatments), it was possible to observe that there was a predominance of the family Poaceae, except for the management with the herbicide glyphosate in which the highest IVI was found for the species Raphanus sativus (Figure 3). In general, the relative density and abundance of species in the area were the parameters that most contributed to the IVI of the different managements.
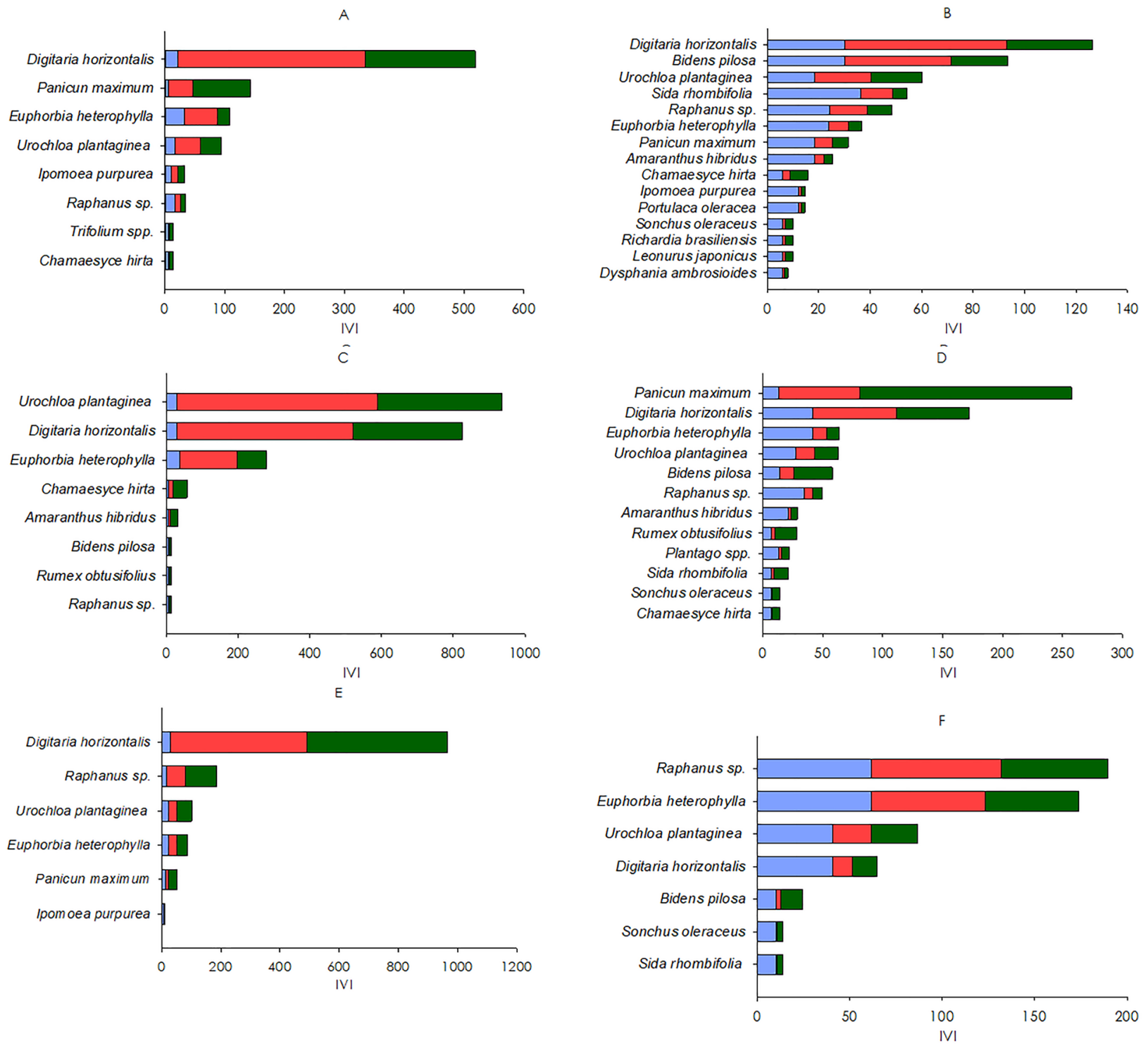

$\square$ Relative frenquency $\square$ Relative density

Relative abundance

Figure 3. Importance value index (IVI) of weeds in fig under the influence of different managements (A) cover maintenance, (B) weeding, (C) lodging, (D) mowing, (E) herbicide diquat and (F) glyphosate herbicide in weed control. São Domingos, Santa Catarina, Brazil.

Weed management presented 15 weed species in the second evaluation, in the first evaluation in this same treatment 10 species were found (Figures 2 and 3). In both evaluations, it was the treatment with greatest species diversity. In places with environmental disturbance, such as soil revolving, some species are favored by this practice and thus begin the process of germination and establishment (De Rossi et al., 2007; Scherner et al., 2016).

The two herbicide managements to control the vegetation cover soil were the ones that showed the lowest diversity of weed species, but the herbicide diquat presented the highest density and relative abundance in the study area (Figure 3 and Table 3).

The maintenance of soil cover in both evaluations showed the lowest weed density, a total of 26 and 125 plants $\mathrm{m}^{-2}$, in the first and second evaluations, respectively. Radicetti et al. (2013) in soil cover work in pepper crop with Avena sativa found that it suppresses 
weeds, regardless of their management, mainly related to species density and diversity. Factors such as luminosity, thermal amplitude and competitiveness may be related to this weed suppression imposed by soil cover (Zibilske \& Makus, 2009; Forte et al., 2018b). De Rossi et al. (2007), in management work of black oat vegetation cover in the pear culture, observed that in the treatments where the black oat was kept on the surface, the daily temperature variation was lower. In treatments where black oats were kept on the surface, it was observed that the thermal protection of the soil was maintained for a longer period, while in the treatment with oat incorporation the thermal protection was no longer efficient, probably due to rapid decomposition of the remaining straw in the soil, exposing it completely, making it similar to control (weeding). As a consequence, incorporated mulching and weeding presented higher species diversity and lower weed suppression, respectively.

The oat cover was the most effective for weed suppression (on average - $93 \%$ of weed above-ground biomass compared to other cover crops). Research has shown the potential of black oats as excellent soil cover both in improving soil physics, chemistry and biology characteristics, as well as in favoring pest control (diseases, insects and weeds) primarily by releasing allelopathic substances or even by physical barrier (De Rossi et al., 2007; Zibilske \& Makus, 2009; Forte et al., 2018a; Forte et al., 2018b).

Table 3. Number of plants (NP) and shoot dry mass (DM - g) per weed species as a function of the method of management of soil cover. São Domingos, Santa Catarina, Brazil.

\begin{tabular}{|c|c|c|c|c|c|c|c|c|c|c|c|c|}
\hline \multirow[t]{2}{*}{ Species } & \multicolumn{2}{|c|}{$\begin{array}{c}\text { Cover } \\
\text { maintenance }\end{array}$} & \multicolumn{2}{|c|}{ Weeding } & \multicolumn{2}{|c|}{ Lodging } & \multicolumn{2}{|c|}{ Mowing } & \multicolumn{2}{|c|}{ Diquat } & \multicolumn{2}{|c|}{ Glyphosate } \\
\hline & NP & DM & NP & DM & NP & DM & NP & DM & NP & DM & NP & DM \\
\hline Sida rhombifolia & 0 & 0 & 15 & 3 & 0 & 0 & 5 & 0 & 0 & 0 & 1 & 0 \\
\hline Digitaria horizontalis & 81 & 20 & 77 & 63 & 157 & 54 & 160 & 58 & 406 & 89 & 12 & 3 \\
\hline Urochloa plantaginea & 11 & 5 & 27 & 3 & 179 & 61 & 35 & 6 & 25 & 9 & 23 & 40 \\
\hline Euphorbia heterophylla & 14 & 5 & 9 & 30 & 51 & 80 & 27 & 34 & 24 & 58 & 68 & 208 \\
\hline Ipomoea purpurea & 3 & 1 & 1 & 2 & 0 & 0 & 0 & 0 & 1 & 0 & 0 & 0 \\
\hline Bidens pilosa & 0 & 0 & 51 & 36 & 1 & 0* & 28 & 61 & 0 & 0 & 3 & 1 \\
\hline Richardia brasiliensis & 0 & 0 & 1 & 8 & 0 & 0 & 0 & 0 & 0 & 0 & 0 & 0 \\
\hline Chamaesyce hirta & 1 & 0 & 1 & 3 & 4 & $0^{*}$ & 3 & 0 & 0 & 0 & 0 & 0 \\
\hline Amaranthus hibridus & 0 & 0 & 5 & 4 & 2 & 13 & 7 & 6 & 0 & 0 & 0 & 0 \\
\hline Panicun maximum & 11 & 59 & 9 & 44 & 0 & 0 & 155 & 207 & 10 & 140 & 0 & 0 \\
\hline Rumex obtusifolius & 0 & 0 & 0 & 0 & 1 & 4 & 8 & 18 & 0 & 0 & 0 & 0 \\
\hline Sonchus oleraceus & 0 & $0^{*}$ & 1 & 3 & 0 & 0 & 3 & 0 & 0 & 0 & 1 & 2 \\
\hline Raphanus sp. & 3 & 1 & 18 & 28 & 1 & 0 & 17 & 94 & 55 & 81 & 77 & 155 \\
\hline Leonurus japonicus & 0 & 0 & 1 & 1 & 0 & 0 & 0 & 0 & 0 & 0 & 0 & 0 \\
\hline Plantago spp. & 0 & 0 & 0 & 0 & 0 & 0 & 5 & 7 & 0 & 0 & 0 & 0 \\
\hline Trifolium spp. & 1 & $0 *$ & 0 & 0 & 0 & 0 & 0 & 0 & 0 & 0 & 0 & 0 \\
\hline Portulaca oleracea & 0 & 0 & 3 & $0^{*}$ & 0 & 0 & 0 & 0 & 0 & 0 & 0 & 0 \\
\hline Dysphania ambrosioides & 0 & 0 & 1 & 1 & 0 & 0 & 0 & 0 & 0 & 0 & 0 & 0 \\
\hline Total & 125 & 89 & 220 & 228 & 396 & 213 & 453 & 491 & 521 & 376 & 186 & 408 \\
\hline
\end{tabular}

De Rossi et al. (2007), when working with different management of black oats in Pyrus communis orchard, observed that weed infestation in the control without soil cover was superior to the other treatments (incorporation of oats in the soil, herbicide desiccation and knife roll lodging; $5 \mathrm{~cm}$ ) and that species diversity was higher when the soil was turned. Ferreira \& Aquila (2000) observed that, among several species of plant cover studied, black oats and rapeseed provided almost total control of the herbs due to their allelopathic effect. According to Forte et al. (2018b) non-tillage and mulching favor weed control in agricultural environment. It is worth mentioning that there are few works related to weed management methods in fig trees, for this reason in the present study we sought literature data from other crops.

\section{Physiological variables of fig tree}

According to the results obtained in the evaluation made on March 29, 2016, it was possible to verify that the type of cover management for weed control did not influence the main variables related to the physiology of the fig crop (Table 4). Most likely, the vegetation cover soil provided improvement in soil moisture and consequently on water use efficiency over a long period, including at the time of evaluation. In peach cultivation, the vegetation cover soil demonstrated in a semi-arid site of China, increases in fruit productivity of $22 \%$ due due to increased water use efficiency with wheat mulch 
(Wang et al., 2015). Weed density, culture age, planting arrangement, irrigation systems can all influence weed control methods and consequently established orchards (Hanson et al., 2017).

Weed competition can prejudice crop development, therefore, regardless of the method used for weed control, it is important that it does not harm the installed crop and preserve its useful life, especially when it comes to herbicides.

Table 4. Variables related to the physiology of fig plants submitted to different weed management methods. São Domingos, Santa Catarina, Brazil.

\begin{tabular}{|c|c|c|c|c|c|c|}
\hline Treatments & $\mathrm{Ci}$ & $E$ & Gs & $\mathrm{A}$ & WUE & CE \\
\hline Cover maintenance & $339,50^{\text {ns }}$ & $4,50^{\mathrm{ns}}$ & $0,27^{\text {ns }}$ & $7,60^{\mathrm{ns}}$ & $1,72^{\mathrm{ns}}$ & $0,02^{\text {ns }}$ \\
\hline Weeding & 337,75 & 4,86 & 0,30 & 6,64 & 1,70 & 0,02 \\
\hline lodging & 330,25 & 5,86 & 0,28 & 8,30 & 1,73 & 0,02 \\
\hline Mowing & 334,75 & 4,98 & 0,33 & 7,65 & 1,83 & 0,02 \\
\hline Diquat & 340,50 & 4,90 & 0,33 & 8,67 & 1,67 & 0,02 \\
\hline Glyphosate & 325,25 & 5,23 & 0,32 & 9,05 & 2,02 & 0,03 \\
\hline C.V. (\%) & 6,50 & 13,83 & 19,65 & 29,73 & 24,95 & 28,22 \\
\hline
\end{tabular}

Fig fruit production

For being slow, the establishment of weeds in managed area with vegetation cover soil in the winter period, the competition imposed by these species did not influence the production of fig performance (Figure 4). Mechanical, cultural or chemical methods provided an average production of $8,811 \mathrm{~kg} \mathrm{ha}^{-1}$ of fig. This fig production average is far below those obtained in countries such as Spain, which production can exceed
20 t ha $^{-1}$ (Pereira et al., 2015). However, very close to the Brazilian productivity, which is $9,990 \mathrm{~kg} \mathrm{ha}^{-1}$ (FAO, 2019). This low production is explained by the fact that the orchard was only established three years ago, considered a plant still young and that its production tends to be higher from the sixth year. Factors such as climate, soil conditions, cultivars and production technology may also be contributing to this difference.

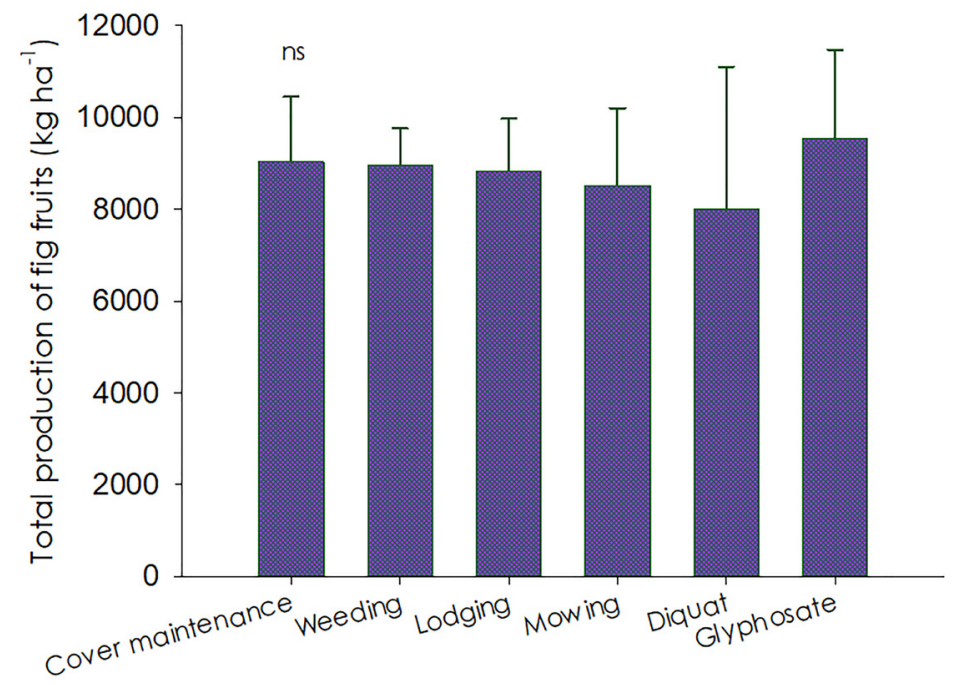

Figure 4. Total production of fig fruits $\left(\mathrm{kg} \mathrm{ha}^{-1}\right)$ in the $2012 / 13 \mathrm{crop}$, in function of soil cover management in the winter period. Data are presented as the means and standard deviation of four independent biological repetitions. ${ }^{n n}$ not significant the probability of error of $5 \%$. São Domingos, Santa Catarina, Brazil.

As it does not change the total fig production, it is advisable to choose methods that reduce environmental and herbicide drift risks to fig plants (cover maintenance, weeding, lodging or mowing) or areas with susceptible crops located near the application. It is also recommended to use fig weed control methods that reduce the impact of rainfall and maintain mulch over a longer period of time, including reducing weed growth (cover maintenance, lodging, herbicides - diquat or glyphosate) and with lower cost to the producer (cover maintenance and lodging). Given these factors, we highlight the maintenance of coverage and lodging as 
the most promising for the management of weeds found fig orchards.

\section{Conclusions}

A wide diversity of weeds was found in the study area, highlighting species of the family Asteraceae and Poaceae. Herbicides provided the lowest species diversity, but not the lowest importance value index.

The methods of soil cover management do not interfere with variables related to the physiology of fig plants and the total yield of fig fruits.

\section{Acknowledgements}

The authors are grateful for the financial support from the National Council for Scientific and Technological Development (CNPq), the Universidade Federal da Fronteira Sul (UFFS) and the availability of Mr. Nercy João da Costa for the availability of the study area.

\section{References}

Alonso-Ayuso, M., Gabriel, J.L., García-González, I., Monte, J.P., Quemada, M. 2018. Weed density and diversity in a long-term cover crop experiment background. Crop Protection 112: 103-111.

Concenço, G., Tomazi, M., Correia, I.V.T., Santos, A.S., Galon, L. 2013. Phytosociological surveys: tools for weed science? Planta Daninha 31: 469-482.

Costa, M.G.S., Correia, E.C.S.S., Reis, L.L., Wilcken, S.R.S. 2015. Reaction of fig tree to three species of root-knot nematodes. Revista Brasileira de Fruticultura 37: 617-622.

De Rossi, A., Rufato, L., Giacobbo, C.L., Costa, V.B., Vitti, M.R., Gonzalez-Mendez, M.E., Fachinello, J.C. 2007. Diferentes manejos da cobertura vegetal de aveia preta em pomar no sul do Brasil. Bragantia 66: 457-463.

EMBRAPA. 2013. Sistema brasileiro de classificação de solos. Embrapa Produção de Informação/Embrapa Solos, Brasília/Rio de Janeiro, Brazil. 353 p.

FAO. Organização das Nações Unidas para Agricultura e Alimentação. 2019. http://apps.fao.org/<Access on 20 sept. 2019>

Favero, C., Jucksch, I., Alvarenga, R.C., Costa, L.M. 2001. Modificações na população de plantas espontâneas na presença de adubos verdes. Pesquisa Agropecuária Brasileira 36: 1355-1362.

Ferreira, A.G., Aquila, M.E.A. 2000. Alelopatia: uma área emergente da ecofisiologia. Revista Brasileira de Fisiologia Vegetal 12: 175-204.

Forte, C.T., Beutler, A.N., Galon, L., Castoldi, C.T., Winter, F.L., Holz, C.M., Bianchessi, F., Concenço, G., Chechi, L., Ferreira, M.M., Andres, A., Burg, G.M. 2018a. Soil physical properties and grain yield influenced by cover crops and crop rotation. American Journal of Plant Sciences 9: 584-
598.

Forte, C.T., Galon, L., Beutler, A.N., Reichert Junior, F.W., Menegat, A.D., Perin, G.F., Tironi, S.P. 2018b. Cultivation systems, vegetable soil covers and their influence on the phytosocyology of weeds. Planta Daninha 36: e018176776.

Giacobbo, C.L., Picolotto, L., Krüger, L.R., Parisotto, E., Tibola, C., Fachinello, J.C. 2007. Cultivo da figueira conduzida em quatro diferentes densidades de plantio. Revista Brasileira de Agrociência 13: 43-46.

Giacobbo, C.L., Galon, L., Zeist, A.R., Guimarães, S., Forte, C.T., Tomazetti, T.C., Lima, A.M., Rossarolla, M.D. 2018. Simulated drift of herbicides applied alone and in tank mix in grapevine. Communications in Plant Sciences 8: 22-30.

Hanson, B.D., Roncoroni, J., Hembree, K.J., Molinar, R., Elmore, C.L. 2017. Weed control in orchards and vineyards. Encyclopedia of Applied Plant Sciences 3: 479-484.

Jakelaitis, A., Ferreira, L.R., Silva, A.A., Agnes, E.L., Miranda, G.V., Machado, A.F.L. 2003. Dinâmica populacional de plantas daninhas sob diferentes sistemas de manejo nas culturas de milho e feijão. Planta Daninha 21: 71-79.

Koning, L.A., Mol, F., Gerowitt, B. 2019. Effects of management by glyphosate or tillage on the weed vegetation in a field experiment. Soil \& Tillage Research 186: $79-86$

Leonel, S. 2008. A figueira. Revista Brasileira de Fruticultura 30: $577-856$.

Müeller-Dombois, D., Ellemberg, H. 1974. Aims and methods of vegetation ecology. John Wiley, New York, USA. 347 p.

Pereira, C., Serradilla, M.J., Martín, A., Villalobos, M.Del.C., Pérez-Gragera, F., López-Corrales, M. 2015. Agronomic behaviour and quality of six fig cultivars for fresh consumption. Scientia Horticulturae 185: 121-128.

Radicetti, E., Mancinelli, R., Campiglia, E. 2013. Impact of managing cover crop residues on the floristic composition and species diversity of the weed community of pepper crop (Capsicum annuum L.). Crop Protection 44: 109-119.

ROLAS. Rede Oficial de Laboratórios de Análise de Solo e de Tecido Vegetal. 2004. Manual de adubação e calagem para os estados do Rio Grande do Sul e Santa Catarina. Sociedade Brasileira de Ciência do Solo, Porto Alegre, Brazil. 400 p.

Santi, A.L., Bona, S.D., Lamego, F.P., Basso, C.J., Eitelwein, M.T., Cherubin, M.R., Kaspary, T.E., Ruchel, Q., Gallon, M. 2014. Phytosociological variability of weed in soybean field. Planta Daninha 32: 39-49.

Scherner, A., Melander, B., Kudsk, P. 2016. Vertical distribution and composition of weed seeds within the plough layer after eleven years of contrasting crop rotation and tillage schemes. Soil \& Tillage Research 161: 135-142. 
Sedaghat, S., Rahemi, M. 2018. Effects of physio-chemical changes during fruit development on nutritional quality of fig (Ficus carica L. var. 'Sabz') under rain-fed condition. Scientia Horticulturae 237: 44-50.

Smith, C.A., Shaw, D.R., Newsom, L.J. 1992. Arrowleaf sida (Sida rhombifolia) and prickly sida (Sida spinosa): germination and emergence. Weed Research 32: 103109.

Wang, H., Wang, C., Zhao, X., Wang, F. 2015. Mulching increases water-use efficiency of peach production on the rainfed semiarid Loess Plateau of China. Agricultural Water Management 154: 20-28.

Westwood, J.H., Charudattan, R., Duke, S.O., Fennimore, S.A., Marrone, P., Slaughter, D.C., Swanton, C., Zollinger, R. 2018. Weed Management in 2050: Perspectives on the future of weed science. Weed Science 66: 275-285.

Zibilske, L.M., Makus, D.J. 2009. Black oat cover crop management effects on soil temperature and biological properties on a Mollisol in Texas, USA. Geoderma 149: 379385.

Conflict of Interest Statement: The authors declare that the research was conducted in the absence of any commercial or financial relationships that could be construed as a potential conflict of interest.

All the contents of this journal, except where otherwise noted, is licensed under a Creative Commons Attribution License attribuition-type BY. 